\title{
Determinants of Merger and Acquisition: An Indian Pharmaceutical Industry Perspective
}

\author{
Pallavi, Ritika Sinha
}

\begin{abstract}
Mergers and acquisitions (M\&A) have gained prominence across the globe as a way of gaining competitive advantage and boosting the profit of the companies. The Indian pharmaceutical industry has readily embraced $M \& A s$ in the recent times and has witnessed a number of profitable deals materialize, while some indeed failed. The success of $M \& A s$ is contingent upon a variety of factors and eventually has a bearing on how the acquiring and target companies perform. This study intended to identify the various factors that either lead to or impede $M \& A s$ and to measure their impact on company performance. The factors that motivate and discourage M\&As were identified and the importance of factors such as deal size and compulsory licensing requirement in $M \& A$ success was assessed and the impact of the all these factors on the performance of the companies was assessed using both primary and secondary data. The encouraging and discouraging aspects of $M \& A$ were found to impact company performance significantly, so did the deal size and compulsory licensing requirement. The findings implied that the success of M\&As depends on a variety of positive and negative factors and the participating companies need to balance these factors judiciously in order to obtain realistic profits from $M \& A s$
\end{abstract}

Keywords: Mergers and Acquisitions, encouraging factors, discouraging factors, deal size, compulsory licensing, company performance.

\section{INTRODUCTION}

In business terms, the process of 'merger', occurs when two or more companies come together to constitute a single legal entity and indulge in transactional exchanges (Megginson and Smart, 2008), following which, the assets and liabilities as well as the shareholders of the participating companies converge (Vazirani, 2015). Likewise, the process of acquisition entails obtaining either entire or a substantial chunk of assets and/ or liabilities and/ or securities of an entire firm, also called target company, or one of its divisions (Daga, 2007). Over the years, mergers and acquisitions (M\&A) have emerged as strategic tool employed by companies to boost their market share, expand operations across the globe and develop novel products The M\&A exercise is brought into effect either by selling non-performing business units or by obtaining resources of another company, such as their technology and workforce. A good number of large and small businesses have opted form M\&A in the last one decade and there has been a transformation in the important sectors of the economy, such as IT, telecommunications, pharmaceuticals, oil etc owing to

Revised Version Manuscript Received on 10, September 2019.

Pallavi, Assistant Professor in Management, Department of Collegiate Education, Govt of Karnataka, Bangalore, Karnataka, And Research Scholar, P.G Department of Management studies (CBSMS), Bangalore University, Bangalore, India

Dr.RitikaSinha, Assistant Professor, Canara Bank School of Karnataka, India. Management studies, Bangalore University Central college, Bangalore,

its proliferation (Roberts, Wallace and Moles, 2012). In general companies opt for M\&A for an assortment of reasons, such gaining operational synergy by sharing resources or reducing costs; obtaining access to the others' know how, and workforce; to obtain tax benefits and so on. The global pharmaceutical industry has embraced M\&As more than any other industry in the world in the recent past and improving the flow of revenue and accessing the global market are the two factors that have facilitated this development (Demirbag, Ng \& Tatoglu, 2007). Increasing costs of production and reducing income from patented medicines are the other important reasons for the proliferation of M\&As in the pharmaceutical industry (Madsen and $\mathrm{Wu}, 2016$ ). The Indian pharmaceutical players have adopted M\&As with an objective of expanding to the foreign markets and gaining competitive advantage in the existing markets apart from benefiting from increasing revenues (Abrol, Prajapati and Singh, 2017). While the Indian pharmaceutical industry has witnessed from a number of high value M\&A deals, domestic (within the country), inbound and outbound (M\&As with overseas firms), which have mostly been successful. However, there have also been instances wherein certain M\&A deals have been disastrous, resulting in considerable losses, both in terms of value and revenue. Therefore, one cannot simply assume that M\&A deals are profitable no matter what and thus, it becomes important to understand the nuances of the M\&A process, such as what leads to companies getting into such deals, what prevents them from doing so, what are the other factors that affect M\&A and how do such factors affect the performance of the companies. With this backdrop, the present study was undertaken with the following objectives

- To determine the factors that motivate and discourage M\&A in the Indian pharmaceutical industry.

- To measure the impact of other factors, such as deal size and compulsory licensing requirement on the success of the M\&A exercise.

\section{LITERATURE REVIEW}

Mergers and Acquisitions and how it affects the companies involved, have captured the fascination of the academic fraternity for long. In one of the important studies on the overseas M\&As, Erel and Weisbach (2012) found that the value of the acquiring and target firms are the important determinants of M\&As, apart from factors, such as the location and stock value of either of the firms. In a similar study based in Turkey, Erdogan (2012) observed that

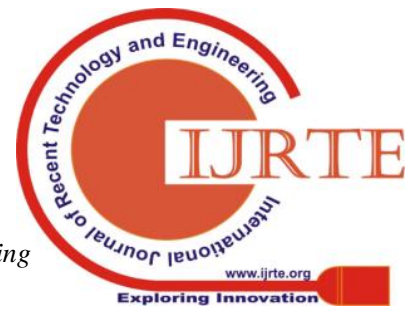




\section{DETERMINANTS OF MERGER AND ACQUISITION: AN INDIAN PHARMACEUTICAL INDUSTRY PERSPECTIVE}

impressive debt ratio of the companies and lower tax rates facilitated better M\&As.

According to the findings obtained by Pathak (2016), improvement in financial status and value the firms is one of the factors that encourages firms to consider M\&As as a lucrative option and also found that tax benefits that come with $\mathrm{M} \& \mathrm{~A}$ is also a motivating factor. Likewise, the author also observed that the anticipation of benefits, such as operating synergy, scope and scales of economy and other legal aspects also encourage firms to initiate M\&A exercise of which operating synergy played the most important part. Similarly, Bedi (2010) and Calipha, Tarba and Brock (2010) also found that factors such as globalization, intended market growth, higher market share, risk reduction due to increased investment, expansion of operations, products and services, etc too played encouraged firms to consider M\&A as a plausible business alternative. Further, the resources at the disposal of acquiring and target firms too played an important role in facilitating $\mathrm{M} \& \mathrm{~A}$ as per the findings obtained by Kohli and Mann (2012). While the aforementioned studies looked into financial and legislative determinants, it was found in a study by Haleblian, McNamara, Kolev and Dykes (2012) that along with the resource base of the firms involved in the M\&A exercise, the organisational structure and culture of both firms also play a major role in whether or not the M\&A materializes.

From a pharmaceutical industry perspective, Jeon, Hong, Ohm and Yang (2015) reported that larger firms acquire smaller firms that are technically robust as they intend to acquire their technical knowledge so as to upscale their drug development, i.e., enhancement of technical knowledge acts as one of the major determinants of M\&As. However, In a similar study on larger firms acquiring smaller ones, Clougherty and Duso, 2011 observed that while large firms indeed benefit by acquiring smaller efficient firms, the benefit might not work both ways, i.e., often larger firms tend to acquire smaller ones without providing them any benefits, which tends to discourage firms from considering M\&As as a plausible option. Further, Madsen and Wu (2016) observed that for acquiring firms, improvement in the market base and scope for further innovation acted as an important motivation for M\&A, while according to Deng and Yang (2015), being able to access better resources, both tangible and intangible, and possibility of creating a niche for themselves in the market motivated the target firms to proceed with M\&A exercise.

Along similar lines, Calipha et al (2010) also observed that the acquiring firms also intend to involve in M\&A exercise as they intend to decrease market combination by either increasing their scale of operations or by reducing the number of competitors through M\&As. Similar views were expressed by Hollenbeck (2018), according to whom competition is one of the major determinants of M\&As. While Kesselhein, Avorn and Sarpatwari (2016) did agree with the above findings, they also observed that while acquiring firms indeed benefit by reducing competition, the target firms do not gain much if the deal was not to their profit. Further, Kumari and Sharma (2019) opined that the act of indulging in M\&As in order to reduce competition would increase the acquiring firm's monopoly in terms of price and product, owing to which, other small firms get affected and such a monopoly will also trouble the customers of the firms, which acts as a demotivating aspect of M\&As. The authors also found that as M\&A results in a larger company, the cost of production will also increase, which in turn demotivates small and medium firms in the matters of M\&A.

Further, government regulations, constitutional framework and legal issues pertaining to the countries of the acquiring and target companies too can either deter and facilitate cross border M\&As, according to a study by Xie, Reddy and Liang (2017), who observed that restrictive government and legal policies demotivate M\&As. Similar views were expressed by Vyas, Narayanan and Ramanathan (2012) in their study on the determinants of M\&A among the Indian pharmaceutical companies, who observed that the economics policy of the country and the funds allocated for R\&D too encouraged M\&As. One among such government regulations, is Compulsory licensing, which entails the removal of patent law and allowing all the pharmaceutical companies, including the company with the patent, to manufacture the drug so that everyone gets access to those medicines and according to the findings of Gandhi (2019), it is one of the major encouraging factors of M\&A. Similar views were expressed by Beall, Kuhn and Attaran (2015), according to which, compulsory licensing encourages the firms to involve in M\&A. While Bognar, Bychkovsky and Lopes Jr. (2016) did agree that compulsory licensing facilitates M\&A, they also observed that compulsory licensing impacts innovation capacity of the firms negatively, thereby impeding the capability of the companies, which eventually impacts the company performance.

The academic fraternity has also been quite keen on studying how M\&A affects the performance of the companies involved. In one such study, Joen et al (2015) observed that M\&A impacts the companies involved mostly by way of improvement in the technology employed, i.e., when the companies acquire novel and advanced technology as a result of M\&As, it has an eventual positive impact on company performance. The authors also found that in such cases, the R\&D activities of the acquiring firms gain a boost, which also affects the company positively. Likewise, in another study by Zhang, Wang, Li, Chen and Wang (2018), M\&As were found to impact company performance positively when resources of the participant companies are merged effectively.

Fich, Nguyen and Officer (2018) regarded the issue from a novel stand point and found that the extent to which firms profit from a M\&A depends on how big is the deal that the participant companies are entering into, thereby, deal size can also be considered a determinant of M\&A. Similar views were expressed by Calipha et al (2010) who found that while deal size does affect how far M\&A affects the companies, but also observed that the capability of the managers of the firms mediates the impact of deal size. Likewise, Masulis and Simsir (2018), found that M\&As do benefit the firms involved; however, opined that the M\&A exercise initiated by the target firms, i.e., firms approaching another firm to initiate the M\&A process, were both common and profitable, 
as it results in the improvement of the performance the target firm, thereby making the M\&A process successful. A detailed review of the determinants, deterrents and the impact of M\&As, indicated that an impressive volume of research studies have attempted to quantify what motivates or demotivates M\&As and how they impact the companies involved. However, these studies do not provide conclusive evidence regarding what exactly makes firms go ahead with the M\&A exercise and how these factors eventually impact company performance.

Two important themes emerged on the basis of literature review, namely, factors that lead to and discourage M\&As; other factors that affect the success of M\&As and thereby the performance of the companies, such as deal size and compulsory licensing. The relationship between these four variables will be measure using the following hypotheses:

Hypothesis 1: Motivating factors for M\&A have a significant impact on the performance of companies.

Hypothesis 2: Discouraging factors of M\&A has a significant impact on the performance of companies.

Hypothesis 3: Deal size has a significant impact on the performance of companies.

Hypothesis 4: Compulsory licensing has a significant impact on the performance of companies.

\section{METHODOLOGY}

The present study adopted a positivistic research philosophy, was both exploratory and descriptive in nature and employed quantitative approach, i.e., used tangible data. The study was conducted in Bengaluru city with the 90 practicing finance professionals working in pharmaceutical companies in the city as study sample. The primary data pertaining to the motivating and demotivating factors of M\&As, impact of deal size, compulsory licensing, etc were collected using structured questionnaires. The reliability of the research instruments was ascertained using Cronbach's Alpha and validated using Factor Analysis. The secondary data pertaining to the performance of the companies, was collected from the annual reports of the companies, various online databases and websites. The literature required for the review was obtained from theses, books, journal articles, etc. Financial ratios pertaining to firm performance were arrived at using MS Excel and these rations, along with the primary data were analysed statistically using the Statistical Package for Social Sciences (SPSS) version 24, using percentages, descriptive statistics, such as mean and standard deviation and regression to test the hypotheses.

\section{RESULTS AND DISCUSSION}

\section{Reliability and Validity}

Reliability analysis was undertaken to measure how far the questionnaire employed capable of yielding the same results, regardless of how many times it is used. All the variables of the study, namely, motivating factors of $\mathrm{M} \& \mathrm{~A}$, discouraging factors M\&A and company performance, the Cronbach's alpha values were between of 0.8-0.9, indicating that the questionnaire is reliable. The highest Cronbach's alpha value of 0.975 was found with regard to the motivating factors of M\&A (12 items), followed by 0.964 for the discouraging factors M\&A ( 7 items) and 0.944 for company performance. The findings of factor analysis implied that the motivating factors of M\&A caused around $79 \%$ variance in the data, while discouraging factors explained $5.83 \%$ of the variance. Similarly, factor loadings for these variables also had a value greater than 0.6 , which implied satisfactory validity (Table 1). On the whole, validity analysis indicated that the questionnaire used for the study had a significant validity and was capable enough to measure the variables of the study effectively.

Table: 2: Factor Analysis for motivating and discouraging factors

\begin{tabular}{|c|c|c|c|}
\hline Factor & Factor loadings & \% of variance & Cumulative \% \\
\hline Motivating factors & & 79.03 & 79.03 \\
\hline $\begin{array}{l}\text { Reverse-engineering capabilities of the pharma } \\
\text { players leading to cheaper manufacture of drugs }\end{array}$ & 0.883 & & \\
\hline Favourable tax regime & 0.863 & & \\
\hline Favourable investment policy & 0.845 & & \\
\hline Corporatisation of health care in the country & 0.824 & & \\
\hline The country's growing medical tourism industry & 0.803 & & \\
\hline $\begin{array}{l}\text { Rising disposable income levels of the local } \\
\text { population }\end{array}$ & 0.770 & & \\
\hline Availability of centres of academic excellence & 0.749 & & \\
\hline Growing popularity of health insurance products & 0.734 & & \\
\hline Incentives provided by the state / central government & 0.704 & & \\
\hline Huge domestic as well as international market & 0.683 & & \\
\hline English language -familiar manpower & 0.679 & & \\
\hline Availability of cheaper manpower in the country & 0.613 & & \\
\hline
\end{tabular}




\begin{tabular}{|c|c|}
\hline Discouraging factors & 84.86 \\
\hline $\begin{array}{l}\text { Inability to forge a solid connect between industry } \\
\text { and curriculum }\end{array}$ & 0.875 \\
\hline Inability to address the industry-institute disconnect & 0.854 \\
\hline Failure to develop novel delivery systems & 0.815 \\
\hline $\begin{array}{l}\text { Inability to ensure availability of qualified } \\
\text { biologists. }\end{array}$ & 0.804 \\
\hline $\begin{array}{l}\text { Inability to ensure availability of state-of-the-art } \\
\text { research infrastructure }\end{array}$ & 0.801 \\
\hline Inability to access cheaper R\&D funds & 0.780 \\
\hline Failure to promote drug discovery research & 0.700 \\
\hline $\begin{array}{l}\text { ctors Motivating Mergers and Acquisitions in the } \\
n \text { Pharmaceutical Industry } \\
\text { out } 9.3 \% \text { of the respondents found that the capacity of } \\
\text { irms to undertake reverse-engineering resulting in } \\
\text { er drug production costs was the topmost motivating } \\
\text { of M\&A, followed by the availability of cheaper } \\
\text { ower in the country }(9.2 \%) \text {. However other factors, } \\
\text { as domestic and international demand, presence of } \\
\text { s of academic excellence, workforce with fluent } \\
\text { sh, tax regime, investment policy of the country, rising } \\
\text { e, etc. played a limited role. Further, the government } \\
\text { tives for M\&A was found to be the least important } \\
\text { At the outset, these findings complement the } \\
\text { vations of Xie et al (2017) that macroeconomic factors }\end{array}$ & $\begin{array}{l}\text { industry encouraged reverse-engineering, which helped firms } \\
\text { reduce production costs (Chaturvedi and Chataway, 2006); } \\
\text { however, after the enforcement of the Trade Related Aspects } \\
\text { of Intellectual Property Rights (TRIPS) regime since 2005, } \\
\text { reverse-engineering of known molecules is no longer a legal } \\
\text { activity (Rai, 2008) However, it is evident from the } \\
\text { respondents' opinion that they still consider that bringing } \\
\text { back reverse-engineering could further motivate M\&A. } \\
\text { Further, cheap labour is one of the important characteristics } \\
\text { of the Indian economy and the same holds good for the } \\
\text { pharmaceutical industry according to Bageria (2019) who } \\
\text { found that the availability of low-cost labour plays attracts } \\
\text { overseas investors to invest in the Indian pharmaceutical } \\
\text { industry, thus cheap labour serves as motivating aspect of } \\
\text { M\&A. }\end{array}$ \\
\hline
\end{tabular}
determine the extent to which M\&As can materialize. Post 2005 the India's policy with regard to pharmaceutical

Table 3: Factors Motivating Mergers and Acquisitions in the Pharmaceutical Industry

\begin{tabular}{clc}
\hline Sl. & Factors & Percent \\
No. & Availability of cheaper manpower in the country & 9.2 \\
\hline 1. & Favourable tax regime & 8.1 \\
3. & Favourable investment policy & 8.0 \\
4. & Incentives provided by the state / central government & 5.8 \\
5. & English language -familiar manpower & 8.5 \\
6. & Availability of centres of academic excellence & 8.7 \\
7. & Huge domestic as well as international market & 8.7 \\
8. & The country's growing medical tourism industry & 8.6 \\
9. & Corporatization of health care in the country & 8.1 \\
10. & Growing popularity of health insurance products & 8.7 \\
11. & Rising disposable income levels of the local population & 8.1 \\
12. & Reverse-engineering capabilities of the pharmaceutical players leading to cheaper manufacture & 9.3 \\
\hline
\end{tabular}

\section{Factors Discouraging Mergers and Acquisitions}

About $15.4 \%$ of the respondents found the inability to address the industry-institute disconnect as the topmost factor that discourages M\&A, followed by the inability to forge a solid connect between industry and curriculum (14.6\%) and the failure to promote drug discovery research. Further, other factors, such as the unavailability of qualified biologists, lack of novel delivery systems, advanced infrastructure, and cheaper R\&D funds played a limited role. On the whole, the discouraging factors implied that the failure of the business system, pharmaceutical research fraternity and the government to create a suitable environment for M\&As demotivates the companies from indulging in M\&As. These findings are also in agreement with Du and Baoteng (2015), who found that excess government regulations and a poor institutional framework impact M\&As negatively. The

disconnect between the Indian pharmaceutical industry and the pharmaceutical education and curriculum emerged as the

biggest deterrents of M\&A as such a disconnection would give rise to qualified, but unemployable professionals in the industry, makes the workforce of the pharmaceutical industry unproductive, which discourages overseas firms from considering M\&A with Indian firms. This rationale was similar to that of Balakrishnan, Thunga, Nair, Kunhikatta and Khera (2018), according to whom, the pharmaceutical graduates lack practical skills, which makes them unsuitable for the industry. Similar views were expressed by Paloskar and Tajne (2018), who found that the present curriculum that 
the pharmaceutical education system follows does not reflect the industry realities accurately, as a result of which pharmaceutical graduates are rendered unsuitable for the market. Therefore, the mismatch between the field level realities and what is taught in classroom is one of the demotivating factors of M\&A.

Table 4: Identifying factors discouraging Mergers and Acquisitions in pharmaceutical industry

\begin{tabular}{clc}
\hline S1. & Factors & Percent \\
\hline 1. & Failure to develop novel delivery systems & 14.1 \\
2. & Failure to promote drug discovery research & 14.3 \\
3. & Inability to forge a solid connect between industry and curriculum & 14.6 \\
4. & Inability to ensure availability of state-of-the-art research infrastructure & 13.7 \\
5. & Inability to ensure availability of qualified biologists. & 14.3 \\
6. & Inability to address the industry-institute disconnect & 15.4 \\
7. & Inability to access cheaper R\&D funds & 13.7 \\
\hline
\end{tabular}

Factors Impacting the Success or Failure of Mergers and Acquisitions

\section{Deal Size}

As high as $71 \%$ of the respondents felt that the size of the M\&A deal is indeed important for the success of the M\&A exercise and the rest $(29 \%)$ felt that deal size did not have bearing on the success of the M\&A deals. As indicated earlier, the review of existing literature on the factors impacting M\&A success implied that the extent to which an M\&D deal succeeds depends on how big or small the deal is as the proportion of resources, technology and economies of scale obtained and revenue earned will depend on the size of the deal. Fich et al (2018) reported that the size of M\&A deals affects the efficiency of M\&As, in turn the profits of the companies involved, thus the M\&A Deal size is indeed one of the most important factors that affects company performance.

\section{Compulsory Licensing}

A huge majority, i.e., about $86 \%$ of the respondents opined that compulsory licensing has a positive impact on the performance of the Indian pharmaceutical companies and the remaining respondents (about 14\%) felt that it affected performance negatively. While government regulations and legal requirements were found to exert an obvious influence on the success or failure of M\&A deals, the review of literature revealed that compulsory licensing requirement was an important factor, which affected the extent to which M\&A deals succeeded. Similar observations were made by Liu (2015) according to whom the compulsory licensing helped smaller firms without innovation and R\&D capabilities to access patented technology, using which they can achieve low cost and high-quality drug production, which makes M\&A successful and improves company performance.

Impact of Motivating Factors of Mergers and Acquisitions on Company Performance
Linear regression analysis revealed that the motivating factors of M\&A, explained $85 \%$ of the variation occurring in company performance and this impact was statistically significant with $\mathrm{F}(1,88)=490.11$ and $\mathrm{p}<0.05$. A highly significant correlation was detected between the independent and dependent variables $(r=0.921)$. Further, a unit change in the motivating factors of $M \& A$ caused $B=0.858$ change in company performance of the company and this relationship was statistically significant $(\mathrm{t}=22.13 ; \mathrm{p}<0.05)$. Hence the encouraging aspects of M\&A altered company performance by $85 \%$, which indicates their importance. As motivating factors of M\&A were found to influence company performance significantly, the hypothesis $\mathrm{H} 1$, which stated that motivating factors for M\&A impact company performance significantly, is accepted.

The findings pertaining to the motivating factors of M\&As are in agreement with the observations made by Abrol et al (2017), according to M\&As enable smaller firms to access the R\&D infrastructure and capabilities of larger firms, which motivates them to indulge in the process and benefits them in the long run. Similar findings were obtained by Kamath (2015), according to which the firms undergoing the M\&A process can access each other's intellectual capital, which eventually improves the market worth, productivity and performance of the firms. According to Chaturvedi and Chataway (2006) before 2005, the Indian pharmaceutical industry thrived on reverse engineering, but the same is not allowed at the moment in India. However, it was still regarded as an important motivating factor of M\&A. Reverse engineering results in lower production costs, which in turn improves company performance. Further, the Indian pharmaceutical industry offers cheap labour, which motivates overseas firms to initiate the M\&A process with Indian players according to Bageria (2019) such M\&A deals boosts company revenues. Therefore, the factors that encourage firms to indulge in the process of M\&A, also benefit the performance of those firms substantially.

Table 5: Model summary for the influence of motivating factors of M\&A on company performance

\begin{tabular}{cccccc}
\hline Variable & B & Standard Error $(\mathbf{B})$ & $\boldsymbol{\beta}$ value & t value & Sig (p) \\
\hline Constant & 0.106 & 0.050 & - & 2.125 & 0.036 \\
Motivating factors & 0.858 & 0.039 & 0.921 & 22.138 & 0.000 \\
\hline
\end{tabular}

R2 - 0.848, $F=490.11, p<0.05$.

Impact of Discouraging Factors of Mergers and Acquisitions on Company Performance

Discouraging factors of M\&A, accounted for as high as 95\% variation in company performance and this impact was statistically significant with $\mathrm{F}(1,88)=1679.58$ and $\mathrm{p}<0.05$. 


\section{DETERMINANTS OF MERGER AND ACQUISITION: AN INDIAN PHARMACEUTICAL INDUSTRY PERSPECTIVE}

Further, an almost perfect significant correlation existed between them $(\mathrm{r}=0.975)$. A unit change in the discouraging factors of $M \& A$ caused $B=0.95$ change in company performance and this relationship was statistically significant $(\mathrm{t}=40.98 ; \mathrm{p}<0.05)$. Hence, the discouraging factors $\mathrm{M} \& \mathrm{~A}$ altered the company performance by $95 \%$, which is an evidence of their importance of those factors. As the discouraging factors of M\&A were found to cause significant changes in company performance, the hypothesis $\mathrm{H} 2$, which stated that the discouraging factors of M\&A impact company performance significantly, is accepted.

The above findings are peculiar in the sense that demotivating factors should have had a negative impact on company performance, but on the contrary, such factors seem to have a positive impact in the present case. These findings are in partial contradiction with the findings of Kesselhein et al (2016), who found that while the M\&A process did benefit the acquiring firms, it failed to influence target firms. Likewise, the findings also contradict the observations of Kumari and Sharma (2019) partially, who found that acquiring firms that indulge in $\mathrm{M} \& \mathrm{~A}$ to reduce competition do benefit from the exercise, but other smaller firms are affected negatively as they find it difficult to survive in the face of the monopolistic power of the acquiring firms, which demotivates smaller firms from encouraging M\&As. Assessment of the various discouraging aspects of M\&A had earlier indicated that the lack of connection between the pharmaceutical industry environment and the learning centres and pharmaceutical curriculum makes the workforce of the industry unsuitable to the industry needs, which in turn demotivates the M\&A process (Balakrishnan et al., 2018). Such a disconnect also affects the productivity of the pharmaceutical firms as the new professionals will need to be trained to meet industry expectations which places a substantial burden on their companies, thereby affecting the company performance. However, the positive impact of industry-curriculum mismatch on company performance is a contradictory observation, which needs to be further explored in future research endeavours.

Table 7: Model summary for the impact of discouraging factors of M\&A on company performance

\begin{tabular}{cccccc}
\hline Variable & B & Standard Error $(\mathbf{B})$ & $\boldsymbol{\beta}$ value & t value & 1.317 \\
Constant & 0.038 & 0.029 & - & & 0.191 \\
Discouraging factors & 0.951 & 0.023 & 0.975 & 40.983 & 0.000 \\
\hline
\end{tabular}

\section{R2-0.950, $F=1679.58, p<0.05$.}

\section{Impact of Deal Size on Company Performance}

The size of the M\&A deal, explained around $58 \%$ variation in company performance. Further, this association between deal size and company performance was statistically significant with $\mathrm{F}(1,88)=121.11$ and $\mathrm{p}<0.05$. Further, highly significant correlation existed between the two $(\mathrm{r}=0.761)$. A unit change in the deal size of M\&A brought about $B=0.577$ change in company performance this impact was statistically significant $(\mathrm{t}=11.00 ; \mathrm{p}<0.05)$. Hence the $\mathrm{M} \& \mathrm{~A}$ deal size altered the company performance by about $58 \%$, which implies that the M\&A deal is moderately important for the companies to perform well. Therefore, as deal size was found to bring about significant changes in company performance, the hypothesis $\mathrm{H} 3$, which stated that deal size impacted company performance significantly is accepted. The above observations are in agreement with the findings of Cuypers, Cuypers and Martin (2012) according to whom, the smaller target firms indeed benefit immensely when they are offered big M\&A deals, which eventually improves their revenue. Similar bigger M\&A deals bring with them equally bigger revenues and sets the economies of scale in motion, which eventually improves company performance according to the observations made by Fich et al (2018).

Table 9: Model summary for the influence of deal size in M\&A on company performance

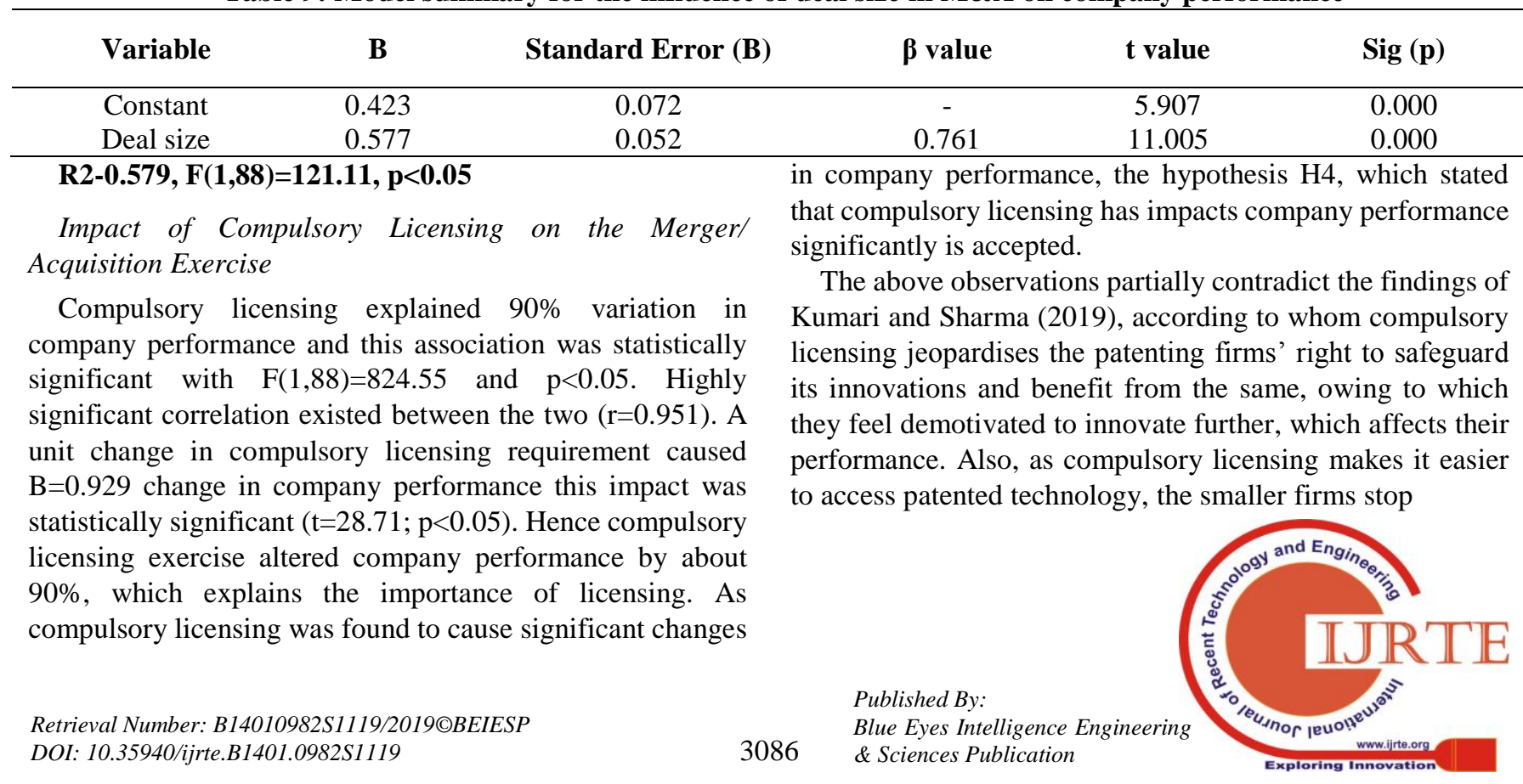


focusing on innovation and $\mathrm{R} \& \mathrm{D}$, which has a negative bearing on the company performance (Bognar et al., 2016), but the present findings clearly contradict these findings as they seem to affect company performance over time. However, the findings are in line with the observations of
Gandhi (2019) who implied that compulsory licensing can help smaller firms access advanced technology, which would help them perform better and similar views were expressed by Liu (2015), who regarded compulsory licensing as beneficial to the particular industry on the whole.

Table 4.72: Model summary of the impact of compulsory licensing on company performance

\begin{tabular}{cccccc}
\hline Variable & B & Standard Error $(\mathbf{B})$ & $\boldsymbol{\beta}$ value & t value & Sig $(\mathbf{p})$ \\
\hline $\begin{array}{c}\text { Constant } \\
\text { Compulsory }\end{array}$ & 0.103 & 0.039 & & 2.669 & 0.009 \\
licensing & 0.929 & 0.032 & 0.951 & 28.715 & 0.000 \\
\hline
\end{tabular}

$R^{2}-0.904, F(1,88)=824.55, p<0.05$.

\section{CONCLUSION}

The present study was undertaken to understand the various factors that encourage and discourage the Indian pharmaceutical companies with regard to M\&As and how these factors eventually impact company performance. The main premise of the study involved identifying the important factors that motivate and discourage M\&As, the importance of size of the M\&A deals and compulsory licensing requirements and measuring the impact of these factors on company performance. The study was quantitative in nature and the data was collected using structured questionnaires from finance professionals employed in different pharmaceutical companies based in Bengaluru city. Reverse-engineering capacity, though the process is no longer allowed, which results in cheaper drug manufacture and the availability of cheap work force were found to be the important factors that motivate M\&As. Likewise, the inability to address the disconnect between industry and pharmaceutical education institutes, inability to build a solid bind between industry and curriculum and failure to promote drug discovery research were the major discouraging factors. Further, deal size and compulsory licensing requirement were also found to be the major determinants of how far an M\&A exercise succeeds, and how the company performs as a result.

The findings of the statistical analysis revealed that all the four dependent variables, namely, motivating factors of M\&As, discouraging factors of M\&A, the size of the M\&A deals and compulsory licensing requirement all exerted a statistically significant influence on the performance of the company. Most of the encouraging and discouraging factors identified during the course of the study pertained to the investment, academic, research and business environment of the country, which implies that the extent to which M\&As occur and the extent to which they succeed more or less depends on how congenial is the investment and business climate of the country and how smooth are the legal processes associated with the same. Likewise, the regulatory and legal processes and requirements associated with the M\&As can either deter the process or speed up the same. The success of M\&As and the post M\&A performance of the acquiring and target companies depends on a lot of things, some of which might be conducive to the process, while the rest might demotivate the companies from going ahead with the process. Therefore, the main takeaway from the present study is that irrespective of all the encouraging, discouraging and other factors, the onus of making an M\&A exercise a success is on the companies involved, which can be achieved only when all the factors are balanced efficiently. Further, the policy makers need to devise frameworks that allow firms to produce at lower costs (similar to reverse-engineering) and also encourage them to innovate further, which will further boost the suitability of the Indian pharmaceutical industry for M\&As.

\section{REFERENCES}

1. Abrol, D., Prajapati, P., \& Singh, N. (2017). Globalization of the Indian pharmaceutical industry: implications for innovation. Institutions and Economies, 3(2), 327-365.

2. Beall, R. F., Kuhn, R., \&Attaran, A. (2015). Compulsory licensing often did not produce lower prices for antiretrovirals compared to international procurement. Health Affairs, 34(3), 493-501.

3. Bageria, S. T. D. S. (2019). SWOT analysis of Indian pharmaceutical industry: In referance to Indian SME pharma industry approaches towards competitive advantage. Journal Current Science, 20(02).

4. Rai, R. K. (2008). Battling with TRIPS: Emerging firm strategies of indian pharmaceutical industry post-TRIPS. Journal of Intellectual Property Rights, 13, 301-317.

5. Chaturvedi, K., \&Chataway, J. (2006). Strategic integration of knowledge in Indian pharmaceutical firms: creating competencies for innovation. International Journal of Business Innovation and Research, 1(1-2), 27-50.

6. Balakrishnan, A., Thunga, G., Nair, S., Kunhikatta, V., \&Khera, K. (2018). Bridging the Gap Between Industry and Academia in Pharmaceutical Education. Indian Journal of Pharmaceutical Education and Research, 52(4), S7-S10.

7. Palsokar, G., \&Tajne, M. (2018). A Study on the Perceived Gap in Between Industry and Academia with Reference to the Curriculum of Post-Graduate Courses In Pharmaceutical Sciences in india. Indian Journal of Pharmaceutical Education and Research, 52(1), 10-20.

8. Bedi, H. S. (2010, February). Merger \& Acquisition in India: An Analytical Study. In National Conference on Business Innovation conducted by Apeejay Institute of Management, Jalandhar-144001, Punjab.

9. Beena, S. (2006). Mergers and acquisitions in the Indian pharmaceutical industry: Nature, structure and performance.

10. Bognar, C. L. F. B., Bychkovsky, B. L., \& Lopes Jr, G. D. L. (2016). Compulsory licenses for cancer drugs: does circumventing patent rights improve access to oncology medications?. Journal of Global Oncology, 2(5), 292-301. 


\section{DETERMINANTS OF MERGER AND ACQUISITION: AN INDIAN PHARMACEUTICAL INDUSTRY PERSPECTIVE}

11. Calipha, R., Tarba, S., \& Brock, D. (2010). Mergers and acquisitions: a review of phases, motives, and success factors. In Advances in mergers and acquisitions (pp. 1-24). Emerald Group Publishing Limited.

12. Clougherty, J. A., \&Duso, T. (2011). Using rival effects to identify synergies and improve merger typologies. Strategic Organization, 9(4), 310-335.

13. Cuypers, I. R., Cuypers, Y., \& Martin, X. (2017). When the target may know better: Effects of experience and information asymmetries on value from mergers and acquisitions. Strategic Management Journal, 38(3), 609-625.

14. Daga, G. (2007). Hindalco Industries Ltd: Hindalco-Novelis Merger Update. Khandwalla Securities, February, 14.

15. Demirbag, M., Ng, C. K., \&Tatoglu, E. (2007). Performance of mergers and acquisitions in the pharmaceutical industry: a comparative perspective. Multinational Business Review, 15(2), 41-62.

16. Deng, P., \& Yang, M. (2015). Cross-border mergers and acquisitions by emerging market firms: A comparative investigation. International Business Review, 24(1), 157-172.

17. Du, M., \&Boateng, A. (2015). State ownership, institutional effects and value creation in cross-border mergers \& acquisitions by Chinese firms. International Business Review, 24(3), 430-442.

18. Erdogan, A. I. (2012). The determinants of mergers and acquisitions: evidence from turkey. International Journal of Economics and Finance, 4(4), 72-77.

19. Erel, I., Liao, R. C., \&Weisbach, M. S. (2012). Determinants of cross-border mergers and acquisitions. The Journal of finance, 67(3), 1045-1082.

20. Fich, E. M., Nguyen, T., \& Officer, M. (2018). Large wealth creation in mergers and acquisitions. Financial Management, 47(4), 953-991.

21. Furtado, R. (2017, March 6). Top ten acquisitions in the pharmaceutical sector in India. Retrieved from https://blog.ipleaders.in/top-ten-acquisitions-in-the-phar maceutical-sector-in-india/

22. Gandhi, B. (2019). India's Compulsory License Model: Increased Pharmaceutical Access and Innovation Coexist. Brigham Young University Prelaw Review, 33(1), 33-57.

23. Haleblian, J., McNamara, G., Kolev, K., \& Dykes, B. J. (2012). Exploring firm characteristics that differentiate leaders from followers in industry merger waves: A competitive dynamics perspective. Strategic Management Journal, 33(9), 1037-1052.

24. Hollenbeck, B. (2018). Horizontal mergers and innovation in concentrated industries. Available at SSRN 2621842.

25. Jeon, J., Hong, S., Ohm, J., \& Yang, T. (2015). Causal relationships among technology acquisition, absorptive capacity, and innovation performance: evidence from the pharmaceutical industry. PloS one, 10(7), e0131642.

26. Kamath, G. B. (2015). Impact of intellectual capital on financial performance and market valuation of firms in India. International Letters of Social and Humanistic Sciences, 48, 107-122.

27. Kesselheim, A. S., Avorn, J., \&Sarpatwari, A. (2016). The high cost of prescription drugs in the United States: origins and prospects for reform. Jama, 316(8), 858-871.

28. Kohli, R., \& Mann, B. J. S. (2012). Analyzing determinants of value creation in domestic and cross border acquisitions in India. International Business Review, 21(6), 998-1016.

29. Kumari, M. K., \& Sharma, A. (2019). Doha Declaration: Compulsory Licensing and Access to Drugs. Global Journal of Medical Research, 19(1), 1-9.

30. Liu, J. (2015). Compulsory Licensing and Anti-Evergreening: interpreting the TRIPS flexibilities in sections 84 and 3 (d) of the Indian Patents Act. Harvard International Law Journal, 56(1), 207-227.

31. Madsen, E. S., \& Wu, Y. (2016). Low R\&D efficiency in large pharmaceutical companies. American Journal of Medical Research, 3(2), 141.

32. Mahajan, V., Nauriyal, D.K., \& Singh, S.P. (2015). Trade performance and revealed comparative advantage of Indian pharmaceutical industry in new IPR regime. International Journal of Pharmaceutical and Healthcare Marketing, 9(1), 56-73.

33. Masulis, R. W., \&Simsir, S. A. (2018). Deal initiation in mergers and acquisitions. Journal of Financial and Quantitative Analysis, 53(6), 2389-2430.

34. Megginson, W., \& Smart, S. (2008). Introduction to corporate finance. Nelson Education.

35. Pathak, Hari Prasad. "Motives for mergers and acquisitions in the Nepalese perspective." Economic Literature, 13 (2016): 9-18.

36. Roberts, A., Wallace, W., \& Moles, P. (2012). Mergers and Acquisitions, United Kingdom, Edinburg Business School. Retrieved on, 10.

37. Suri, F. K., \&Banerji, A. (2016). Super Generics-First Step of Indian Pharmaceutical Industry in the Innovative Space in US Market. Journal of Health Management, 18(1), 161-171.

38. Varun, D. (2007). Post merger profitability analysis of shareholders, evidence from Europe (Doctoral dissertation, University of Nottingham).

39. Vazirani, N. (2015). A Literature Review on Mergers and Acquisitions Waves and Theories.

40. Vyas, V., Narayanan, K., \&Ramanathan, A. (2012). Determinants of mergers and acquisitions in Indian pharmaceutical industry. Eurasian Journal of Business and Economics, 5(9), 79-102.

41. Xie, E., Reddy, K. S., \& Liang, J. (2017). Country-specific determinants of cross-border mergers and acquisitions: A comprehensive review and future research directions. Journal of World Business, 52(2), 127-183.

42. Zhang, W., Wang, K., Li, L., Chen, Y., \& Wang, X. (2018). The impact of firms' mergers and acquisitions on their performance in emerging economies. Technological Forecasting and Social Change, 135, 208-216. 